\title{
TIPOLOGI DAN MORFOLOGI FASADE RUMAH TRADISIONAL KAMPUNG CIPTAGELAR
}

\author{
Syamsun Ramli \\ Universitas Brawijaya Malang \\ apuirek@gmail.com
}

\section{ABSTRACT}

Keywords: Facade, Traditional house, Socio-economic, Climate change, Insight, Tatali Paranti Karuhun

The people of Kampung Ciptagelar are indigenous people who still hold tatali paranti karuhun. The traditional house of Ciptagelar village is rumah panggung. The facade of the traditional house of Kampung Ciptagelar has developed. The purpose of this research is to describe typology and morphology of traditional house of Kampung Ciptagelar. This research is descriptive research using qualitative data collection techniques. Primary data was obtained through observing the field. Secondary references are obtained through historical-comparative research related to the research sites and research topics. The results showed that there are two types of roofs, three types of roof terraces, six door types, eight types of windows, two types of walls, and four types of terraces. The researcher classifies the change of facade of traditional house of kampong into eight groups. The change of facade is influenced by social, economic, climate change, and community knowledge of Kampung Ciptagelar. Tatali paranti karuhun as a cultural factor while maintaining the red thread of the traditional house of Kampong Ciptagelar.
\end{abstract}

Kata Kunci: Fasade, Rumah tradisional, Sosial-ekonomi, Perubahan iklim, Wawasan, Tatali Paranti Karuhun

\begin{abstract}
ABSTRAK
Masyarakat Kampung Ciptagelar adalah masyarakat adat yang masih memegang tatali paranti karuhun. Rumah tradisional kampung Ciptagelar adalah rumah panggung. Fasade rumah tradisonal Kampung Ciptagelar mengalami perkembangan. Tujuan penelitian adalah menggambarkan tipologi dan morfologi fasade rumah tradisional Kampung Ciptagelar. Penelitian ini adalah descriptive research menggunakan teknik pengumpulan qualitative data. Data primer diperoleh melalui mengobservasi lapangan. Referensi sekunder diperoleh melalui penelitian historis-komparatif yang terkait dengan lokasi penelitian dan topik penelitian. Hasil penelitian menunjukan terdapat dua jenis atap rumah, tiga jenis atap teras, enam jenis pintu, delapan jenis jendela, dua jenis dinding, dan empat jenis teras. Peneliti mengelompokan perubahan fasade rumah tradisional kampung menjadi delapan kelompok. Perubahan fasade dipengaruhi oleh faktor sosial, ekonomi, perubahan iklim, dan wawasan masyarakat Kampung Ciptagelar. Tatali paranti karuhun sebagai faktor budaya tetap menjaga benang merah fasade rumah tradisional Kampung Ciptagelar.
\end{abstract}




\section{Pendahuluan}

Kesatuan Adat Banten Kidul (KABK) merupakan komunitas adat yang berada di Kabupaten Sukabumi. KABK terdiri dari Kasepuhan Citorek, Kasepuhan Cicarucub, dan Pancer Pangawinan. Masyarakat Pancer Pangawinan mempunyai tradisi berpindah-pindah tempat (ngalalakon) (Nuryanto, 2006). Jika Masyarakat Pancer Pangawinan berpindah tempat, maka pusat pemerintahan adat akan berpindah juga (Kusdiwanggo, 2013). Pada saat ini Ibu Kota pemerintahan adat berada di Kampung Ciptagelar yang pada awalnya bernama Kampung Cikarancang. Ciptagelar berasal dari cipta (Encup Sucipta sebagai ketua adat) dan gelar yang berarti ngagelarkeun (memperlihatkan diri) (Nuryanto, 2006). Kampung Ciptagelar resmi dihuni pada 12 April 2000 (Kusdiwanggo, 2016a). Sehingga saat ini dikenal dengan nama Kasepuhan Ciptagelar. Kasepuhan merujuk pada himpunan dari banyak lembur dan kampung yang terikat secara adat dan budaya (Kusdiwanggo, 2016a). Masyarakat Kampung Ciptagelar adalah masyarakat adat yang masih memegang tatali paranti karuhun (aturan adat yang diturunkan dari nenek moyang). Kampung merupakan kesatuan manusia yang memiliki empat ciri, yaitu (1) interaksi antar warganya, (2) adat istiadat, (3) norma-norma hukum, dan (4) aturan khas yang mengatur seluruh pola tingkah lakunya (Koentjaraningrat, 1990).

Rumah tradisional kampung Ciptagelar adalah rumah panggung. Rumah tradisonal adalah rumah yang dibangun dengan cara yang sama dari generasi ke generasi dengan tanpa atau sedikit sekali perubahan (Yudohusodo, 1991). Arsitektur tradisional ialah suatu bangunan dengan bentuk, struktur, fungsi, ragam hias dan cara pembuatannya diwariskan secara turun temurun.

Fasade rumah tradisonal Kampung Ciptagelar mengalami perubahan. Peneliti mengelompokan perubahan fasade rumah tradisional Kampung Ciptagelar menjadi delapan kelompok.

Tipologi adalah ilmu yang mempelajari tipe dari obyek-obyek arsitektural, kemudian mengelompokkannya ke dalam suatu klasifikasi tipe berdasarkan kesamaan yang dimiliki oleh obyek arsitektural tersebut dalam hal-hal tertentu (Prijotomo, 1997). Pendekatan tipologi biasanya selalu dimulai dengan objek atau entitas yang sudah ada sebelumnya (Plowright, 2014). Tipologi adalah suatu upaya untuk "mengkelaskan", mengelompokkan atau mengklasifikasikan berdasar aspek atau kaidah tertentu. Aspek tersebut antara lain: 1. Fungsi (meliputi penggunaan ruang, struktural, simbolis, dan lain-lain); 2. Geometrik (meliputi bentuk, prinsip tatanan, dan lain-lain); dan 3. Langgam (meliputi periode, lokasi atau geografi, politik atau kekuasaan, etnik dan budaya, dan lain-lain) (Sulistijowati, 1991). Kriteria tertentu dalam tipologi adalah bentuk (bangun), sifat dasar, fungsi dan asal usul yang dimiliki oleh obyek tersebut (Prijotomo, 1997). Elemen wajah dari sebuah bangunan adalah: (1) Atap; (2) Dinding; dan (3) Lantai (Lippsmeier, 1980).

Morfologi adalah studi mengenai form dan shape dari lingkungan permukiman. Form berarti bentuk yang dapat diamati dan merupakan konfigurasi dari beberapa objek, sementara shape adalah fitur geometrik atau bentuk eksternal dan outline dari sebuah benda (Carmona, 2003).

\section{Permasalahan}

Rumah tradisional Kampung Ciptagelar mengalami perubahan, dan sedang mengalami tantangan akan keasliannya. Di sini kearifan komunitas adat terhadap lingkungannya bekerja dan menentukan apakah mereka dapat bertahan terhadap perubahan atau tidak (Ismet Belgawan, 2011). 


\section{Tipologi dan Morfologi Fasade Rumah Tradisional Kampung Ciptagelar}

Syamsun Ramli

\section{Tujuan Penelitian}

Tujuan penelitian adalah untuk mengetahui tipologi dan perubahan fasade rumah tradisional Kampung Ciptagelar.

\section{Metode Penelitian}

Penelitian ini adalah descriptive research, sehingga penjelasan disajikan secara deskriptif. Penelitian menggunakan teknik pengumpulan qualitative data. Data primer diperoleh melalui field research, yaitu mengobservasi fasade rumah tradisional Kampung Ciptagelar. Referensi sekunder diperoleh melalui penelitian historis-komparatif yang terkait dengan lokasi penelitian dan topik penelitian (Neuman, 2014). Data primer yang diperoleh yaitu: (1) foto (2) hasil wawancara. Referensi sekunder yaitu peta Kampung Ciptagelar.

Peneliti bertindak sebagai recognized outsider, sehingga peneliti sebagai orang yang mengamati namun kehadiran pengamat diketahui oleh masyarakat Kampung Ciptagelar Ciptagelar.

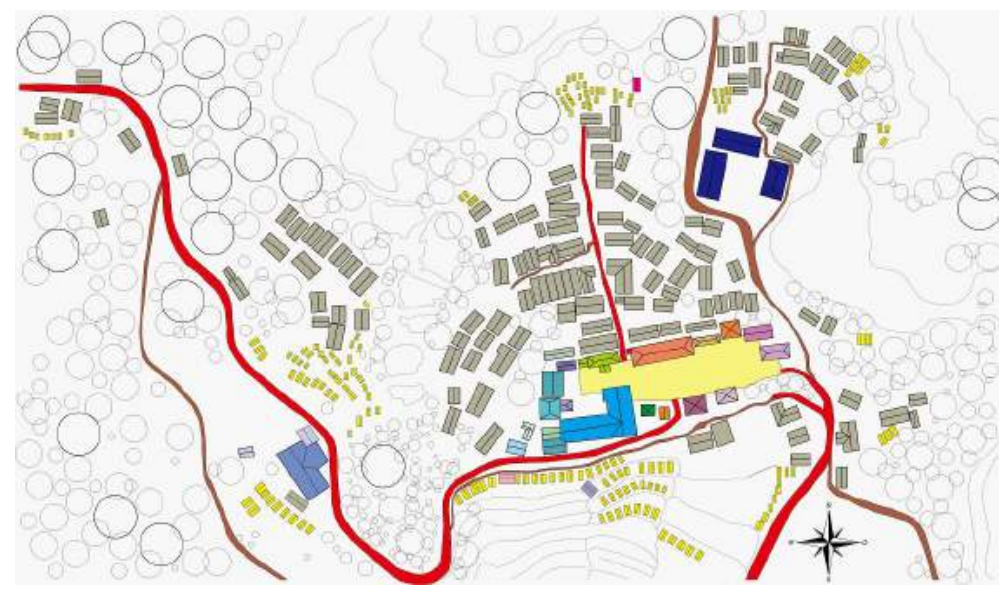

Gambar 1. Lokasi penelitian (Sumber: Syamsun, 2018)

Lokasi penelitian adalah Kampung Ciptagelar, Desa Sinar Resmi, Kecamatan Cisolok, Kabupaten Sukabumi, Provinsi Jawa Barat.

Sampel penelitian yaitu delapan belas rumah tradisonal Kampung Ciptagelar. Sampel rumah diambil berdasarkan perubahan yang ada pada fasade rumah tradisional Kampung Ciptagelar. Ada delapan kelompok perubahan, yaitu (1) fasade rumah sudah digunakan jendela kaca dengan sampel sebanyak empat rumah, (2) fasade rumah sudah ditambah tepas dengan sampel sebanyak dua rumah, (3) fasade rumah sudah digunakan teras plesteran dengan sampel sebanyak dua rumah, (4) fasade sudah ditambah atap depan dengan sampel sebanyak dua rumah, (5) fasade rumah sudah ditambah tepas dan atap depan dengan sampel sebanyak dua rumah, (6) fasade berubah karena perubahan fungsi ruang depan dengan sampel sebanyak satu rumah, (7) fasade berubah karena penambahan ruang depan dengan sampel sebanyak tiga rumah, (8) fasade berubah karena rumah sudah dua lantai dengan sampel sebanyak dua rumah. 
Variabel tipologi fasade rumah adalah sebagai berikut:

Tabel 1. Variabel Penelitian

\begin{tabular}{cll}
\hline No. & Variabel & Sub Variabel \\
\hline 1 & Atap rumah & Bentuk dan material \\
2 & Atap teras & Bentuk dan material \\
3 & Pintu & Jumlah, posisi, dan warna \\
4 & Jendela & Jumlah dan warna \\
5 & Dinding & Bentuk, material, dan warna \\
6 & Teras & Bentuk dan material \\
\hline
\end{tabular}

Analisis data menggunakan metode kualitatif rasionalistik. Metode penelitian kualitatif rasionalistik didasarkan pada pemahaman intelektual dengan kemampuan berargumentasi secara logis dan didukung oleh data yang relevan (Muhadjir, 2002).

Analisis morfologi fasade rumah tradisional Kampung Ciptagelar berdasarkan perubahan fasade rumah dengan melihat faktor sosial, ekonomi, perubahan iklim, wawasan, dan budaya masyarakat Kampung Ciptagelar.

\section{Pembahasan}

Fasade masih tetap menjadi elemen arsitektur terpenting sampai dengan abad 20 yang mampu menyuarakan fungsi suatu bangunan (Krier, 2001). Fasade rumah tradisional Kampung Ciptagelar memiliki:

- Dua tipe atap rumah.

- Tiga tipe atap teras.

- Dua tipe daun pintu.

- Delapan tipe jendela.

- Dua tipe dinding.

- Empat tipe teras.

Iklim tropis, kelembaban, keselarasan alam dan manusia, nilai kearifan, nilai kebersamaan dan dinamika budaya sangat mempengaruhi bentuk fisik bangunan Nusantara (Nugroho, 2015).

Masyarakat Pancer Pangawinan pada awalnya adalah masyarakat tertutup. Pada tahun 2000, ketika Ibu Kota pemerintahan adat pindah dari Kampung Ciptarasa ke Kampung Cikarancang, Abah Anom (Encup Sucipta) sebagai Sesepuh Girang (ketua adat) mulai membuka diri terhadap lingkungan luar. Sehingga nama kampung berubah menjadi Kampung Ciptagelar. Ciptagelar berasal dari cipta (Encup Sucipta) dan gelar yang berarti ngagelarkeun (memperlihatkan diri) (Nuryanto, 2006). Walaupun Masyarakat Pancer Pangawinan sudah membuka diri dimana masyarakat luar dapat melihat adat istiadat dan upacara adat, namun hal-hal yang berkaitan dengan rahasia, misalnya doa-doa dan makna dibalik upacara adat masih dipegang teguh oleh masyarakat Kampung Ciptagelar terutama para Baris Kolot. 
Pada awalnya rumah tradisional Masyarakat Pancer Pangawinan adalah rumah panggung, berlantai talupuh, dan semuanya bertiang bambu (Abah Asep Nugraha, 2017). Ada pepatah bahwa rumah itu hateup salak tihang cagak, artinya rumah harus sederhana yang penting tidak menghilangkan fungsinya (Rusnandar, 2014).

Perubahan petama pada fasade rumah adalah dengan digunakannya jendela kaca. Keputusan ketua adat untuk membuka diri dan menerima teknologi, termasuk penggunaan material kaca berpengaruh terhadap fasade rumah tradisional Kampung Ciptagelar.

Jendela kaca digunakan untuk mendapat pencahayaan alami di dalam rumah. Hal ini sebagai pengaruh dari dinamika budaya dimana rumah bukan lagi hanya sebagai tempat istirahat di malam hari, namun menjadi tempat beraktivitas di siang hari. Sumber cahaya alami yang berlimpah merupakan potensi sumber penerangan bangunan. Bangunan tropis di Indonesia masih tetap relevan menggunakan pencahayaan alami. Pengaturan bentuk, perletakan ruang dan elemen-elemen bangunan, seperti jendela, memungkinkan pemanfaatan pencahayaan alami pada siang hari (Antaryama, 2007).

Penggunaan warna-warna alam yaitu hijau, coklat, putih, kuning pada pintu, jendela, maupun dinding mencerminkan masyarakat Kampung Ciptagelar yang dekat dengan alam. Kecenderungan pemilihan warna dipengaruhi oleh pertimbangan warna dominan di lingkungannya (Yoshizawa, Hibino, \& Koyama, 2015).

Penggunaan daun jendela ukuran besar memberikan keuntungan dalam penghawaan alami. Penghawaan alami mempunyai manfaat, yaitu (1) membuang panas dalam ruang, (2) membuang kelembaban, dan (3) memberi sensasi sejuk pada manusia (Nugroho, 2015). Penggunaan daun jendela ukuran besar dipengaruhi oleh perubahan iklim yang berdampak pada suhu lingkungan yang semakin panas pada saat siang hari.

Bentuk atap jolopong maupun parahu kumureb dengan kemiringan atap sekitar $45^{\circ}$ membuat air hujan cepat terbuang. Bentuk atap jolopong merupakan bentuk atap yang sederhana, sesuai dengan sifat masyarakat Pancer Pangawinan yang sederhana. Atap menggunakan material alami yaitu daun tepus dan ijuk.

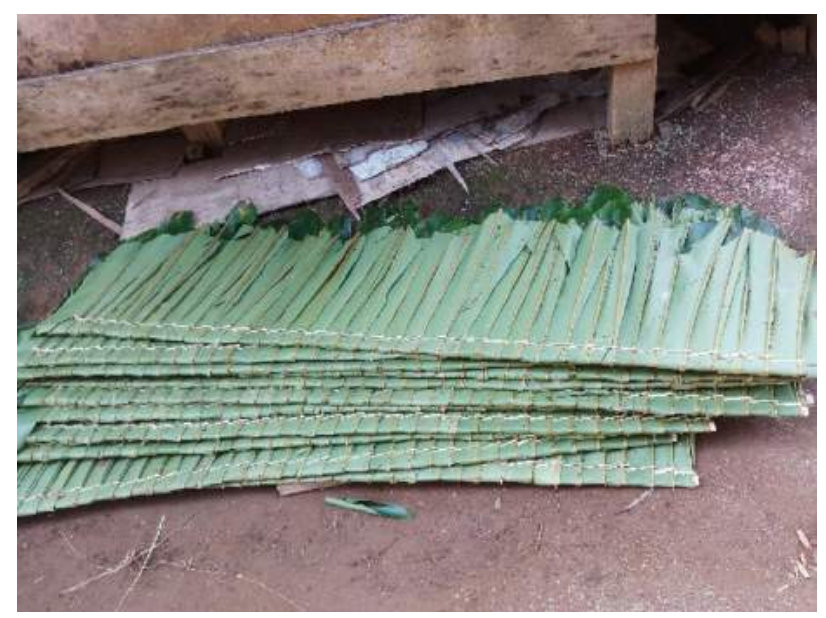

Gambar 2. Material atap daun tepus

(Sumber: Syamsun, 2018) 


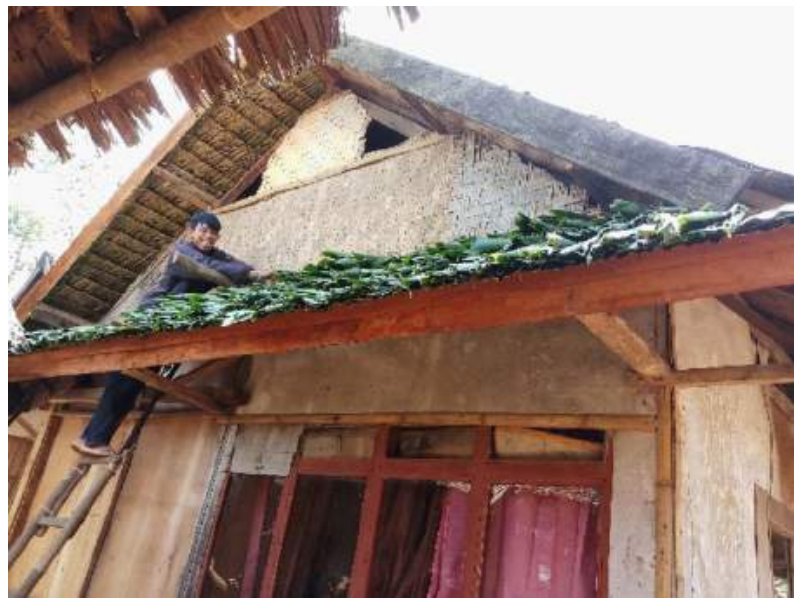

Gambar 3. Pemasangan atap daun tepus (Sumber: Syamsun, 2018)

Material alami pada atap memilki hantaran panas yang kecil di mana radiasi matahari cepat diserap dan dilepaskan kembali (Nugroho, 2015).

Atap rumah ada yang hanya menggunakan satu lapisan yaitu lapisan daun tepus, ada juga yang mengunakan dua lapisan, yaitu lapisan bawah daun tepus dan lapisan atas ijuk. Kang Jahod sebagai tukang atap di Kampung Ciptagelar atap mengemukakan bahwa lapisan bawah tepus dan lapisan atas injuk mempunyai keawetan sampai dengan 20 tahun. Pilihan untuk menggunakan satu lapisan atap atau dua lapisan atap dipengaruhi oleh kemampuan ekonomi masyarakat Kampung Ciptagelar. Hal ini karena harga ijuk menurut Kang Jahod terbilang mahal, sehingga tidak semua warga mampu menggunakan ijuk sebagai material atap.

Pada awalnya rumah tradisional Kampung Ciptagelar menggunakan satu daun pintu. Namun belakangan ini rumah yang baru dibangun menggunakan dua daun pintu. Sehingga rumah lama pada saat pintunya diperbaiki menjadi menggunkan dua daun pintu. Perubahan selanjutnya adalah penempatan pintu di tengah-tengah antar jendela, sehingga letak jendela dan pintu menjadi simetris. Perubahan ini disebabkan adanya pengaruh lingkungan dan wawasan baru masyarakat dari lingkungan di luar kasepuhan.

Dinding rumah tradisional rumah Kampung Ciptagelar adalah dinding datar dengan material bilik. Bilik adalah anyaman dari bambu yang dibelah tipis-tipis. Bilik biasa terbuat dari bagian dalam (daging) bambu. Bilik hinis terbuat dari bagian kulit bambu yang lebih keras dari daging bambu. Bilik hinis lebih awet dan lebih mahal dari bilik biasa. Disamping karena bambu banyak ditemukan di Kampung Ciptagelar, juga karena tatali paranti karuhun mengharuskan penggunaan material alam untuk rumah, seperti bambu, daun tepus, dan ijuk.

Bilik merupakan indigenous knowledge dinding ramah lingkungan. Dinding ramah lingkungan adalah elemen arsitektur yang memungkinkan udara leluasa bergerak. Dinding ramah lingkungan membuat ruangan menjadi sejuk, tidak pengap dan nyaman (Nugroho, 2015).

Perbedaan penggunaan bilik bisasa dan bilik hinis disebabkan karena perbedaan kemampuan ekonomi pemilik rumah. Masyarakat dengan kemampuan ekonomi yang lebih tinggi menggunakan 


\section{Tipologi dan Morfologi Fasade Rumah Tradisional Kampung Ciptagelar}

Syamsun Ramli

bilik hinis sebagai material dinding. Masyarakat Kampung Ciptagelar mengecat dinding bilik biasa menggunakan kapur, sehingga mayoritas cat dinding berwarna putih, namun bilik hinis tidak dicat sama sekali.

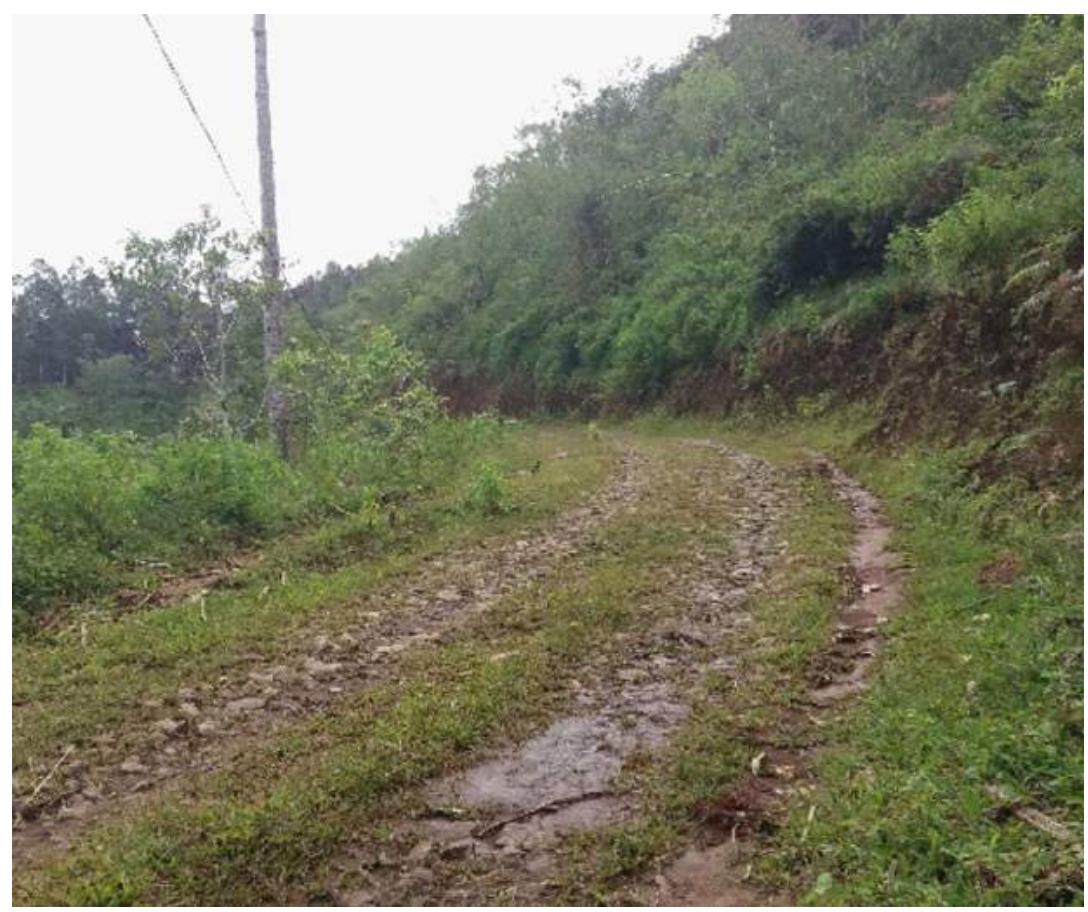

Gambar 4. Kondisi jalan menuju Kampung Ciptagelar (Sumber: Syamsun, 2018)

Perubahan bentuk dinding disebabkan oleh perubahan fungsi ruang dan penambahan ruang di depan rumah. Perubahan fungsi ruang yaitu merubah ruang depan menjadi warung. Penambahan ruang di depan rumah yaitu menambah ruang sebagai warung maupun bengkel motor. Perubahan fungsi ruang maupun penambahan ruang berdampak pada perubahan fasade rumah. Kehidupan masyarakat Pancer Pangawinan masih melestarikan tradisi leluhur yang berazaskan budaya padi (Kusdiwanggo, 2016b). Masyarakat Pancer Pangawinan mempunyai tradisi melarang memperjualbelikan padi, beras, maupun nasi. Masyarakat Pancer Pangawinan memperoleh penghasilan dari hasil hutan, kebun, atau penjualan ikan yang pelihara pada saat sawah tidak ditanami padi. Sehingga usaha warung menjadi salah satu alternatif mata pencaharian masyarakat Kampung Ciptagelar. Di sisi lain bertambahnya jumlah sepeda motor yang dimiliki masyarakat, membuat keberadaan bengkel motor menjadi penting di Kampung Ciptagelar. Kebutuhan akan warung dan bengkel juga tidak terlepas dari letak kampung yang berada di tengah hutan. Jarak dari Desa terdekat (Desa Sinar Resmi) yaitu 11,1 KM dengan kondisi jalan makadam berbukit-bukit. Waktu tempuh dari Desa Sinar Resmi ke Kampung Ciptagelar adalah 2 jam. 
LOCAL WISDOM, Vol. 10 No. 2 Juli 2018

Local Wisdom Scientific Online Journal

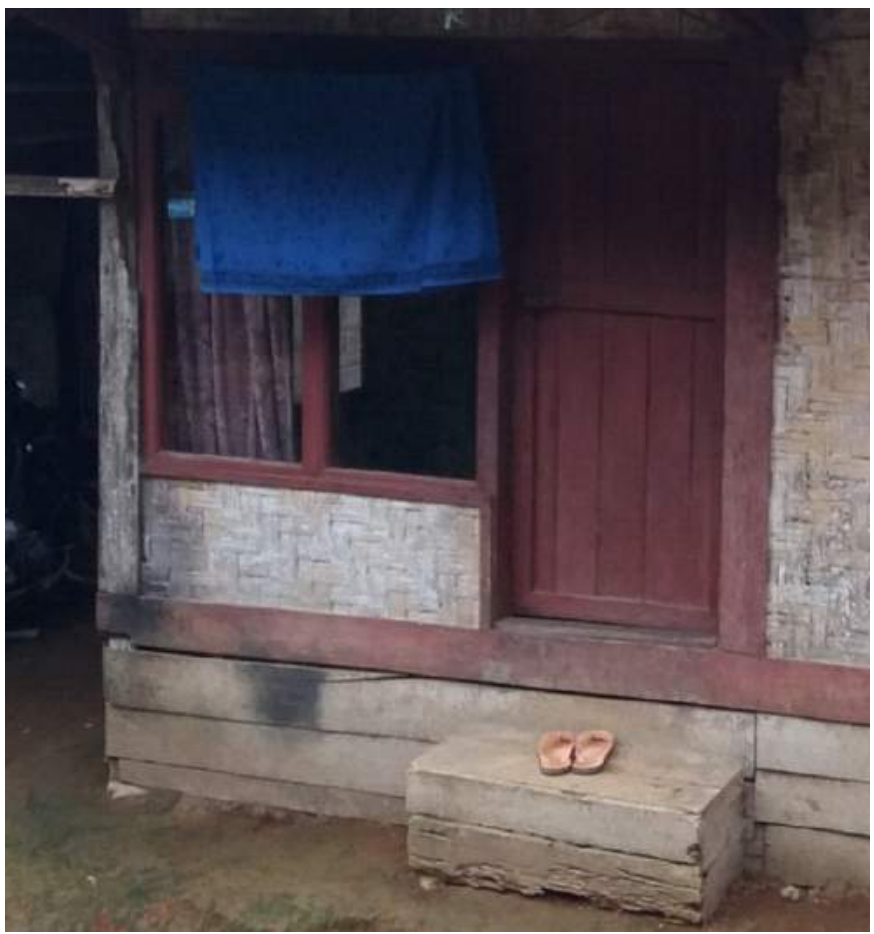

Gambar 5. Golodog

(Sumber: Syamsun, 2018)

Rumah tradisional Kampung Ciptagelar pada awalnya adalah rumah panggung dengan golodog. Gologod adalah tangga kecil untuk naik ke rumah panggung dengan ukuran selebar pintu. Tamu dari kalangan tetangga dan keluarga dekat biasanya langsung menuju pawon (dapur). Pawon bagi masyarakat Sunda tidak hanya berfungsi untuk aktivitas memasak, tetapi juga memiliki fungsi sosial dan fungsi ritual (Nuryanto, 2004). Pawon merupakan ruang sosial karena pada jaman dahulu suhu lingkungan masih sangat dingin, sehingga penghuni rumah maupun tamu lebih nyaman di pawon yang mempunyai suhu lebih hangat dengan adanya hawu. Hawu adalah tungku tempat memasak. Pada sore hari penghuni rumah lebih nyaman berkumpul di pawon.

Perubahan iklim membuat suhu lingkungan Kampung Ciptagelar tidak sedingin dahulu, sehingga masyarakat pada sore lebih nyaman berada luar rumah pada sore hari. Suhu rata-rata sekarang adalah $27^{\circ} \mathrm{C}$ (climate-data.org, 2018). Masyarakat lebih senang berkumpul dan mengobrol dengan tetangga di luar rumah pada sore hari. Untuk memfasilitasi hal tersebut, maka dibuatlah tepas di depan rumah. Tepas adalah lantai panggung di depan rumah yang berfungsi sebagai teras dengan tinggi sejajar dengan lantai rumah. 


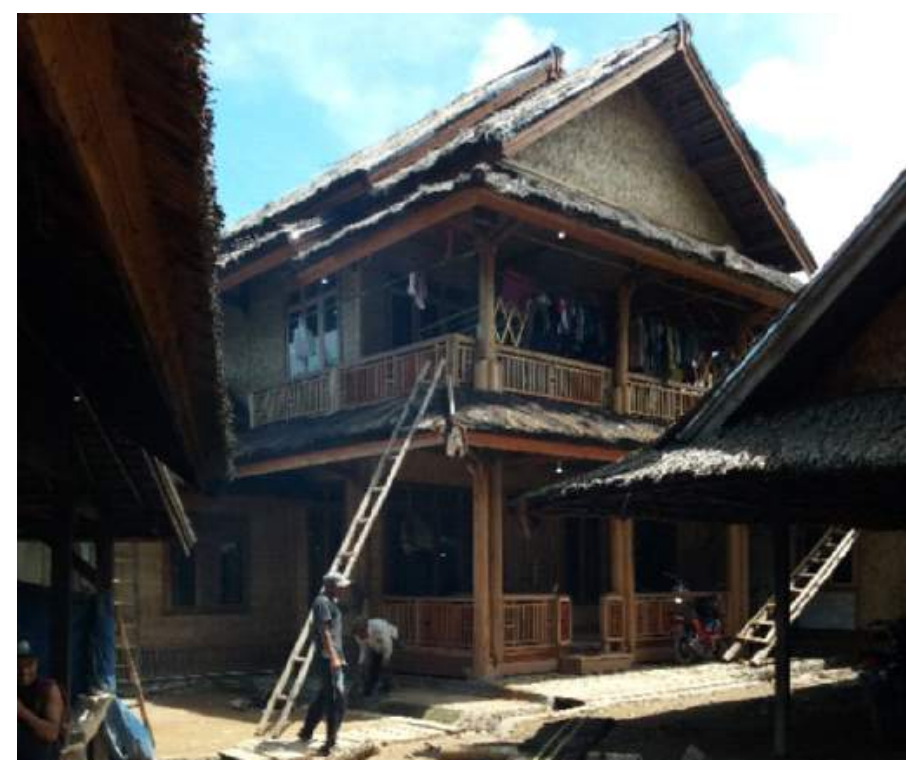

Gambar 6. Rumah Ketua Adat Kasepuhan Ciptagelar (Sumber: Syamsun, 2018)

Rumah yang sudah berlantai dua pada awalnya disebabkan letak rumah pada daerah yang curam, sehingga lantai bawah merupakan tambahan ruangan. Namun rumah ketua adat berlantai dua menjadi cermin kedudukan pemilik rumah sebagai Sesepuh Girang yang memilki status sosial dan ekonomi yang paling tinggi di masyarakat Kampung Ciptagelar.

\section{Kesimpulan}

Tipologi fasade rumah tradisional Kampung Ciptagelar memiliki dua tipe atap rumah, tiga tipe atap teras, dua tipe daun pintu, delapan tipe jendela. dua tipe dinding, empat tipe teras.

Perubahan fasade rumah tradisional Kampung Ciptagelar dipengaruhi oleh dipengaruhi oleh faktor sosial, ekonomi, perubahan iklim, dan wawasan masyarakat Kampung Ciptagelar.

Tatali paranti karuhun sebagai faktor budaya tetap menjaga benang merah fasade rumah tradisional Kampung Ciptagelar, yaitu aturan bahwa rumah harus menggunakan material dari alam seperti penggunaan bambu, beratap daun tepus dan/atau ijuk.

\section{Referensi}

Abah Asep Nugraha. (2017). Wawancara mengenai Imah Tradisional Masyarakat Pancer Pangawinan. Antaryama, I. G.. (2007). Arsitektur Cerdas: Sebuah Perpaduan antara Teknologi, Arsitektur dan Alam Indonesia (Architectu). Carmona, M. (2003). Public Places, Urban Spaces: the dimensions of urban design. Oxford: Architectural Press.

climate-data.org. (2018). Suhu wilayah. Retrieved June 5, 2018, from https://id.climate-data.org/search/?q=cisolok Ismet Belgawan, N. R. (2011). Arsitektur Rumah dan Permukiman Tradisional di Jawa Barat. Dinas Pariwisata Dan Kebudayaan Provinsi Jawa Barat.

Koentjaraningrat. (1990). Pengantar Ilmu Antropologi. Jakarta: Rineka Cipta. 
Krier, R. (2001). Komposisi arsitektur. Jakarta: Erlangga.

Kusdiwanggo, S. (2013). Membaca Ngalalakon pada Komunitas Adat Ciptagelar sebagai Masyarakat Peladang, 3742.

Kusdiwanggo, S. (2016a). Konsep Pola Spasial Permukiman Di Kasepuhan Ciptagelar. Jurnal Permukiman, 11(1), 4356.

Kusdiwanggo, S. (2016b). Sakuren/ : Konsep Spasial sebagai Prasyarat Keselamatan Masyarakat Budaya Padi di Kasepuhan Ciptagelar, 26(3), 309-322.

Lippsmeier, G. (1980). Bangunan Tropis (2nd ed.). Jakarta: Erlangga.

Muhadjir, N. (2002). Metode Penelitian Kualitatif(IV). Yogyakarta: Rake Sarasin.

Neuman, W. L. (2014). Social Research Methods: Qualitative and Quantitative Approaches. Relevance of social research (Vol. 8). https://doi.org/10.2307/3211488

Nugroho, A. M. (2015). Seri Rumah Nusantara (I) Tumah Ramah Lingkungan. In Seri Rumah Nusantara. Dinas PU Cipta Karya dan Tata Ruang Provinsi Jawa Timur.

Nuryanto. (2004). Fungsi dan Makna Pawon pada Arsitektur Rumah Tradisional Masyarakat Sunda.

Nuryanto. (2006). Ruang Publik dan Ritual Warga Kampung Kasepuhan Ciptagelar di Kabupaten Sukabumi, 4859.

Plowright, P. D. (2014). Typology as Minimal Complexity Typology as Minimal Complexity, (July). https://doi.org/ 10.13140/2.1.2861.8886

Prijotomo, J. (1997). Bunga Rampai Arsitektur ITS Surabaya. Surabaya: Jurusan Arsitektur Fakultas Teknik Sipil dan Perencanaan Institut Teknologi Sepuluh November Surabaya.

Rusnandar. (2014). Arsitektur Tradisional di Kasepuhan Sinar Resmi Kabupaten Sukabumi Jawa Barat. Patanjala, $6(3)$.

Sulistijowati, M. (1991). Tipologi Arsitektur Pada Rumah Kolonial Surabaya (Dengan Kasus Perumahan Plampitan dan Sekitarnya). Surabaya.

Yoshizawa, Y., Hibino, H., \& Koyama, S. (2015). Color Selection of Architectural Façade Taking into Consideration Surrounding Environment in Japan.

Yudohusodo, S. (1991). Rumah untuk Seluruh Rakyat. INKOPPOL 
Tipologi dan Morfologi Fasade Rumah Tradisional Kampung Ciptagelar Syamsun Ramli

\begin{tabular}{|c|c|c|c|}
\hline 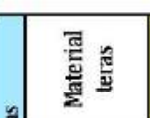 & 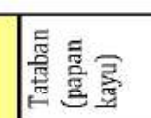 & 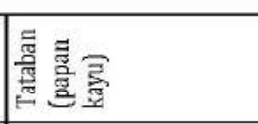 & 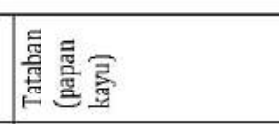 \\
\hline 善量 & 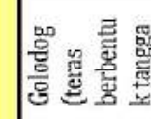 & 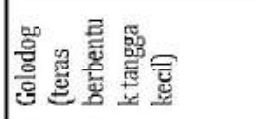 & 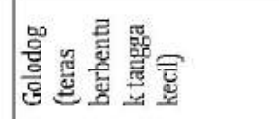 \\
\hline 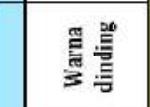 & 言 & 鄫总 & 辤 \\
\hline 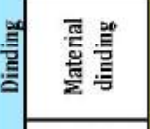 & 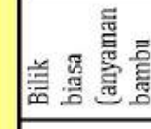 & 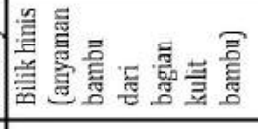 & 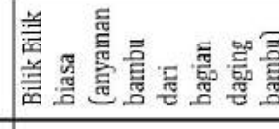 \\
\hline 盢喜 & 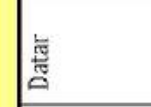 & 㩊 & 总 \\
\hline 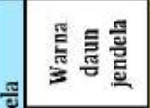 & 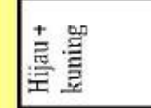 & 愛 & 壾 \\
\hline 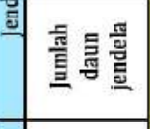 & 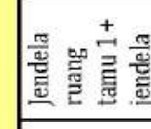 & 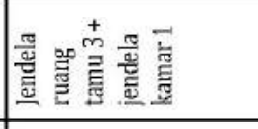 & 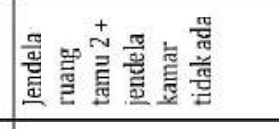 \\
\hline 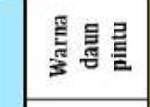 & 递蒡 & 畨 & 蓓 \\
\hline 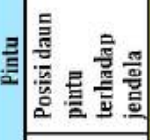 & 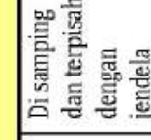 & 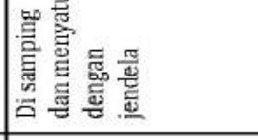 & 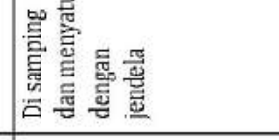 \\
\hline 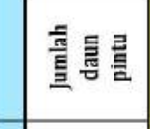 & 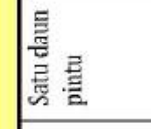 & 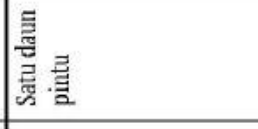 & 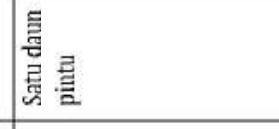 \\
\hline 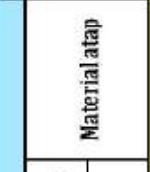 & 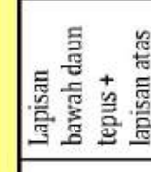 & 产 & 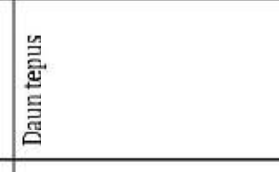 \\
\hline 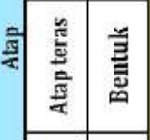 & 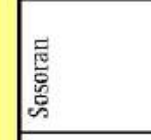 & 喆 & 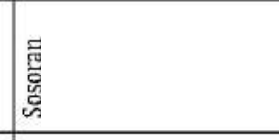 \\
\hline 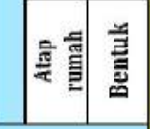 & 量 & 言 & \begin{tabular}{|l} 
言 \\
言 \\
吾
\end{tabular} \\
\hline$\stackrel{\frac{8}{2}}{\frac{1}{2}}$ & & & \\
\hline 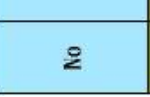 & - & N & $\mathrm{m}$ \\
\hline
\end{tabular}


LOCAL WISDOM, Vol. 10 No. 2 Juli 2018

Local Wisdom Scientific Online Journal

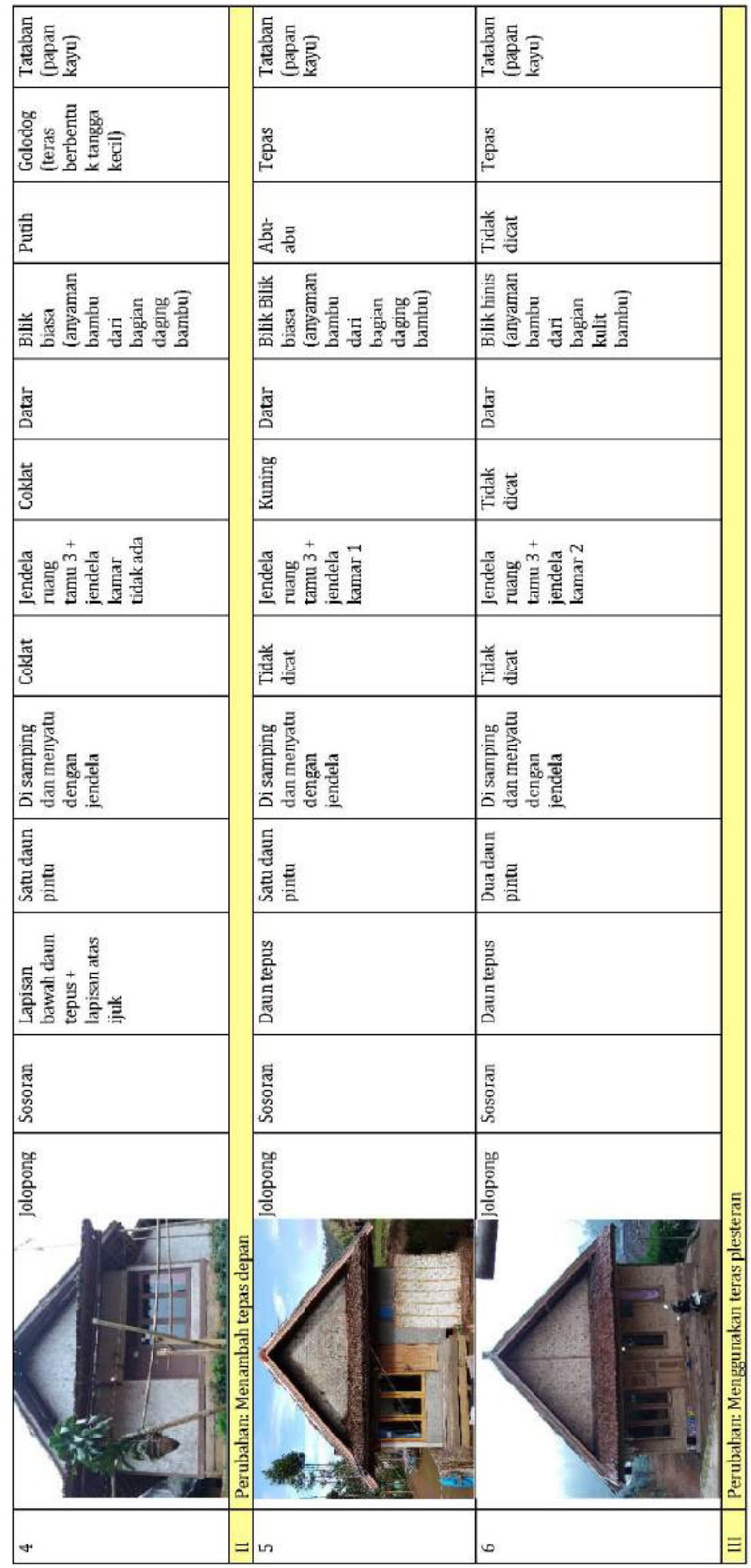


Tipologi dan Morfologi Fasade Rumah Tradisional Kampung Ciptagelar Syamsun Ramli

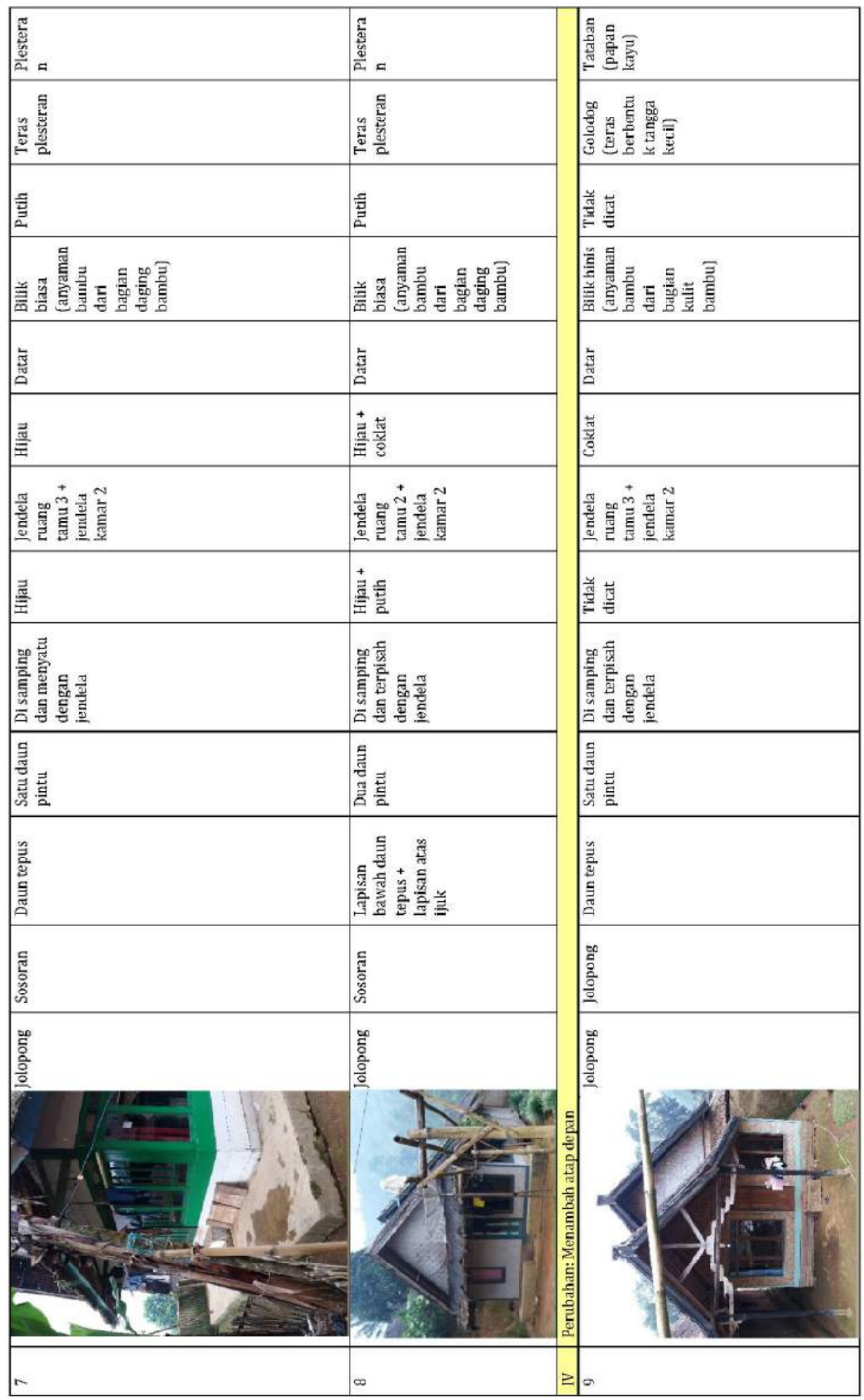


LOCAL WISDOM, Vol. 10 No. 2 Juli 2018

Local Wisdom Scientific Online Journal

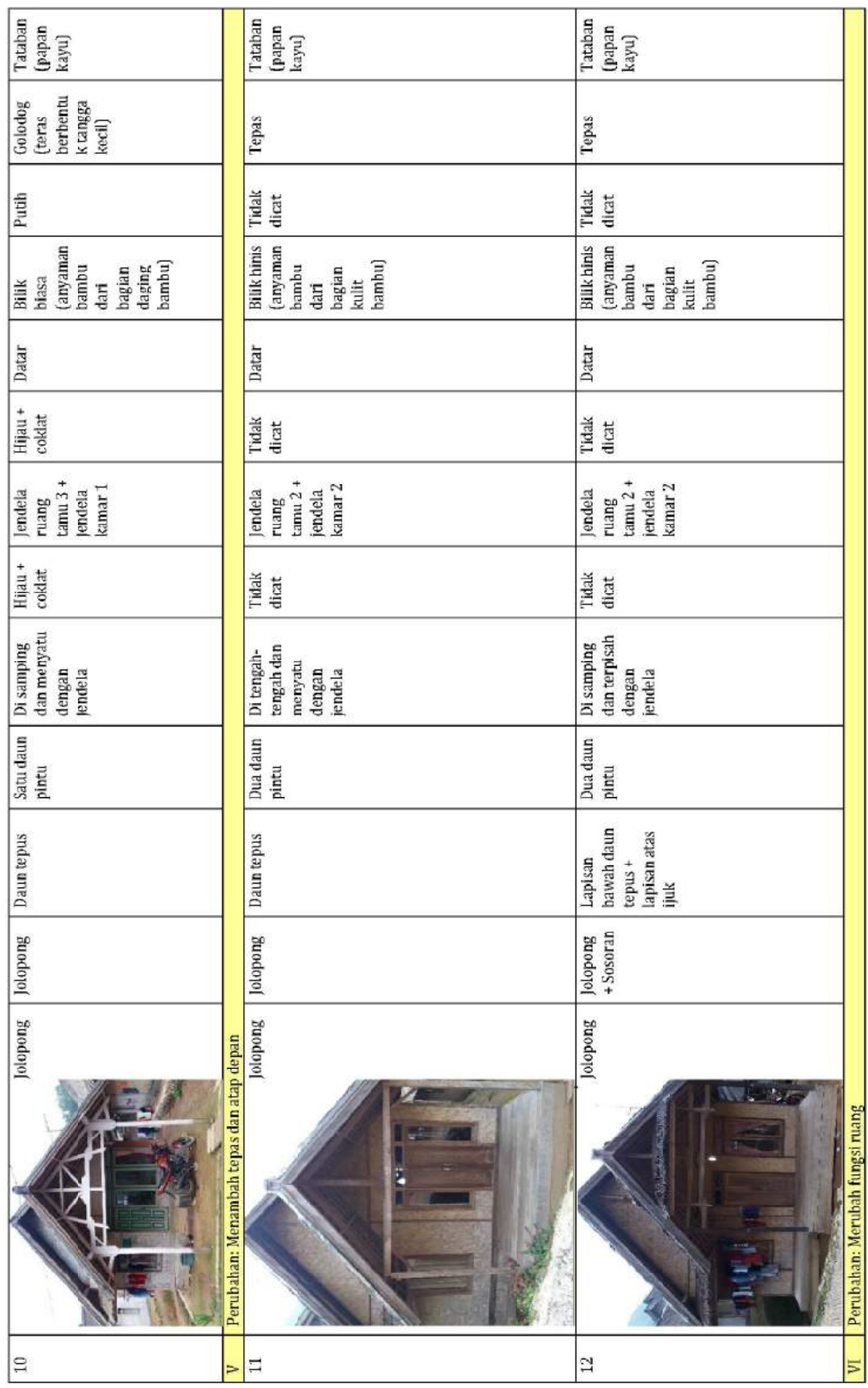


Tipologi dan Morfologi Fasade Rumah Tradisional Kampung Ciptagelar Syamsun Ramli

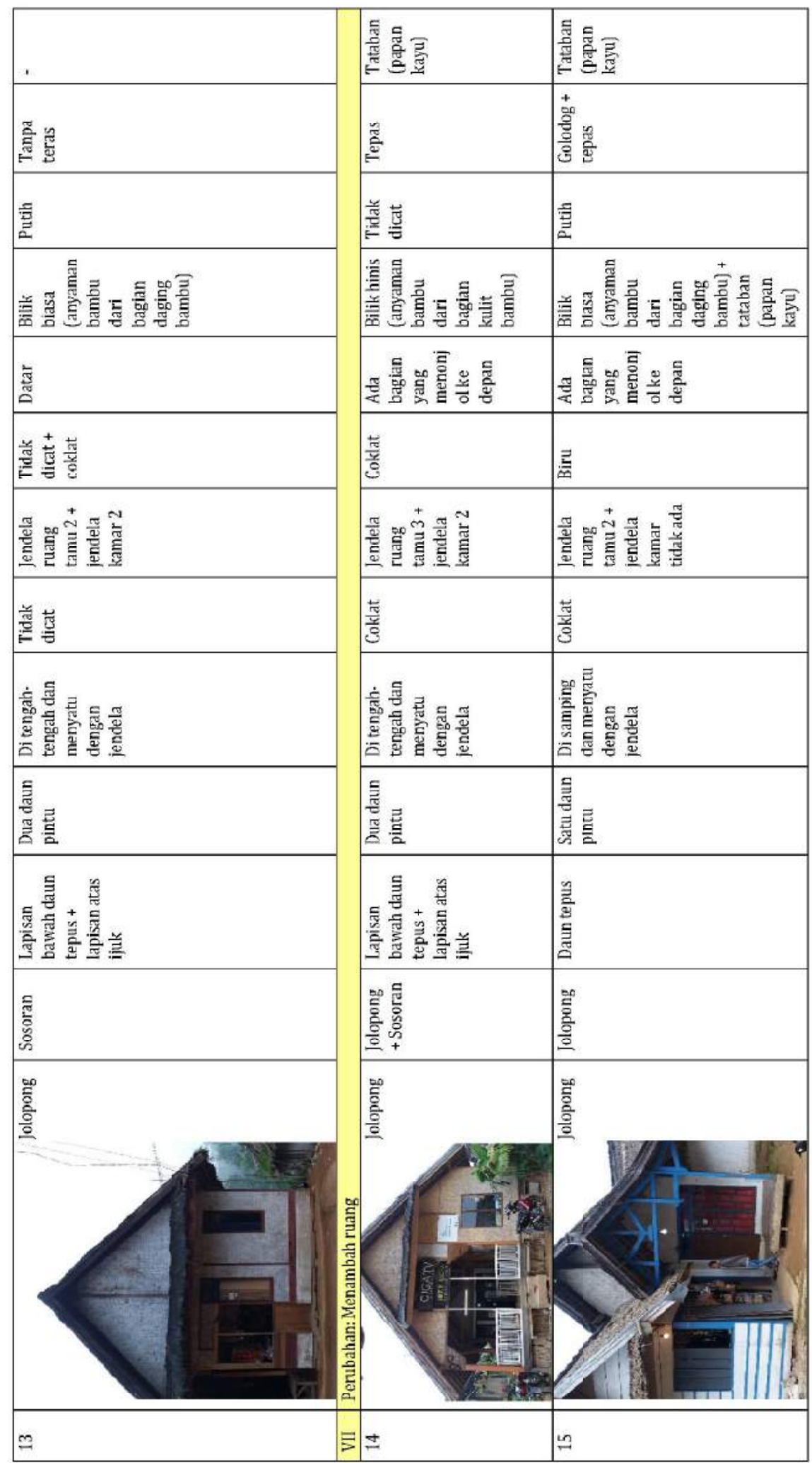


LOCAL WISDOM, Vol. 10 No. 2 Juli 2018

Local Wisdom Scientific Online Journal

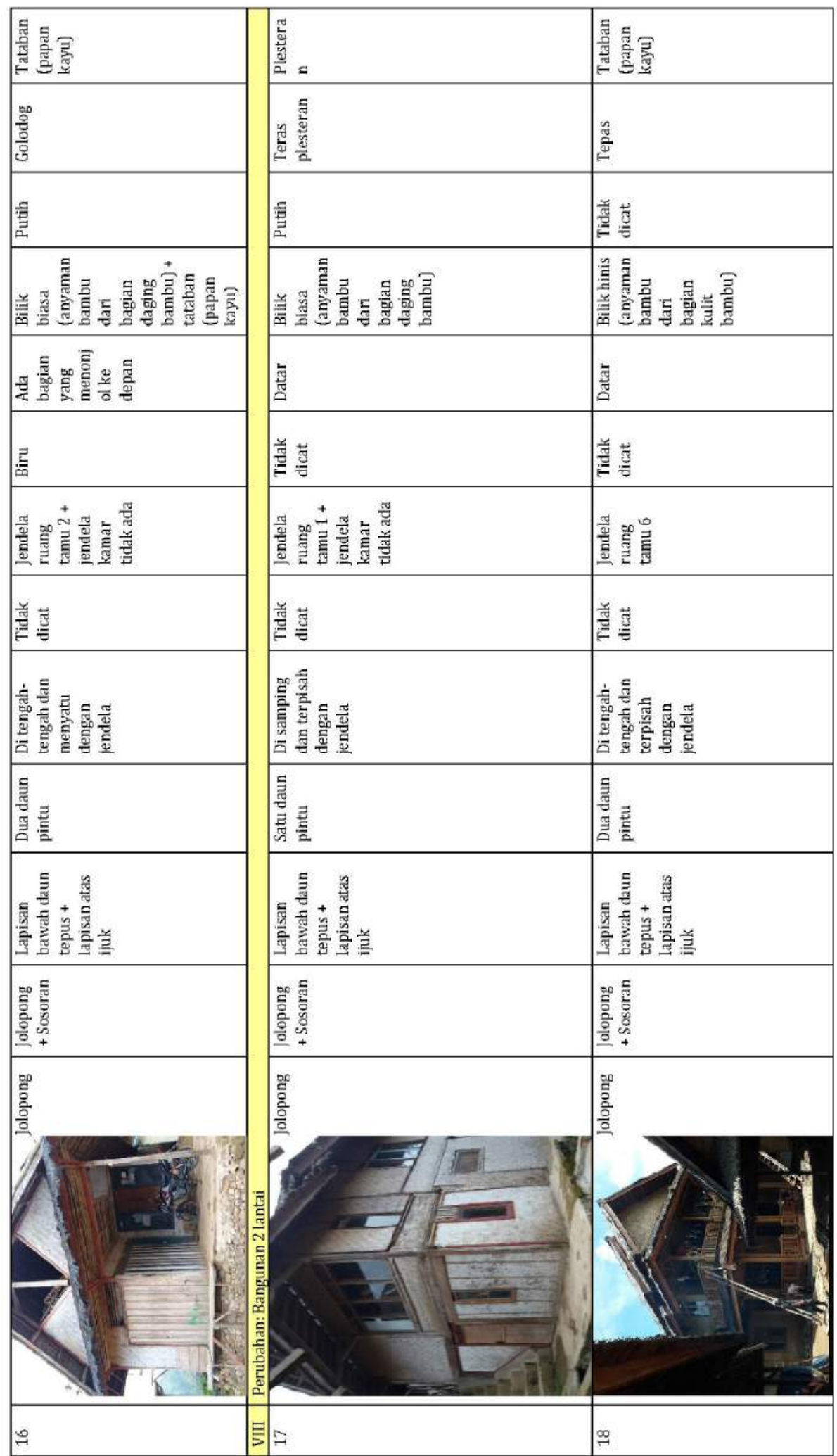

